\title{
Measuring the bioavailable/toxic concentration of copper in natural water by using anodic stripping voltammetry and Vibrio-qinghaiensis sp.Nov.-Q67 bioassay
}

\author{
Shengbiao Huang, Zijian Wang* and Mei Ma \\ State Key Laboratory of Environmental Aquatic Chemistry, Research Center for Eco-Environmental Sciences, \\ Chinese Academy of Sciences and National Environmental Protection Agency, Beijing, 100085 China
}

\begin{abstract}
Bioassays were carried out in the culture media for Vibrio-qinghaiensis sp.Nov.-Q67 and the influences of alkalinity and different concentrations of chloride, ethylene diamine tetraacetic acid (EDTA) and natural derived fulvic acid (FA) on the labile concentration and toxicity of $\mathrm{Cu}$ were investigated. The labile concentration of $\mathrm{Cu}$ was obtained by differential pulse anodic stripping voltammetry with a double acidification method (DAM-DPASV). Changes in water alkalinity and chloride concentrations did not affect the labile concentration of $\mathrm{Cu}$, but increases of alkalinity and concentrations of chloride reduced the toxicity on Q67. In the presence of EDTA and FA, both labile concentration of $\mathrm{Cu}$ and toxicity were reduced. By excluding $\mathrm{Cu}$-carbonate complexes and $\mathrm{Cu}-\mathrm{chloride}$ from labile concentration, a bioavailable concentration of $\mathrm{Cu}$ (or [Cu*]) was obtained and used to predict the acute toxicity of $\mathrm{Cu}$ on Q67. For natural waters, the labile concentration of $\mathrm{Cu}$ was measured by DAM-DPASV and $\left[\mathrm{Cu}^{\star}\right]$ was calculated by a MINTEQ A2 software based on composition of waters. This procedure was tested for Guanting Reservoir waters by spiking different concentration $\mathrm{Cu}$. The results showed that [Cu*] was a good indicator for $\mathrm{Cu}$ toxicity and could be used in field conditions.
\end{abstract}

Keywords: copper speciation, acute toxicity, Q67, natural waters

\section{INTRODUCTION}

Bioavailability and toxicity of trace metal to aquatic organisms depend on the physical and chemical forms of the metal. ${ }^{1}$ Therefore the speciation of a metal, rather than its total concentration, is the key to understanding its effect on the biota. ${ }^{2}$ Previous studies on several metals and varieties of aquatic organisms have demonstrated that the organism responding to metals could be modeled by using its free ion activity. 3,4 Morel formulated the free-ion-activity model (FIAM) for metalorganism interaction. ${ }^{5}$ The FIAM has generally been

*To whom correspondence should be addressed:

E-mail: wangzj@mail.rcees.ac.cn used to interpret that a constant degree of biological effect will occur at a constant chemical activity of the metal free ion. These studies have led to the conviction that the concentration of free ionic metal is the key determinant of toxicity. While it might be tempting to conclude that the free-ion alone is responsible for observed toxicities, this appears to be not supportable. ${ }^{6}$

Free-ion activity does not appear to be a good predictor of toxicity across some water quality conditions (e.g. water hardness), and does not explain the competition of experimental metal ion with other cations. ${ }^{7}$ Building on that concept, forming biotic-ligand model (BLM), a recently surface-interaction model of metal binding to fish gill simultaneously incorporates relative of metal speciation with its toxicity and competition between experimental metal ion and other cations. ${ }^{8,9}$ 
Thus, adopting BLM could help predict acute toxicity of $\mathrm{Cu}$ to fish on a mechanistic basis and in various conditions of water hardness. But there are some factors that should be investigated over time that may improve the model's predictability and improve our understanding of its strength or limitations. ${ }^{10}$ For example, in testing the model's ability to predict $\mathrm{Cu}$ toxicity, BLM assumed DOC to be $10 \%$ of humic acid and the conditional stability constant of $\mathrm{Cu}$ with humic acid is not a site-specific parameter. ${ }^{11}$

Anodic stripping voltammetry (ASV) is a powerful tool for the study of trace element speciation, which can be used to provide speciation information regarding to the labile/inert discrimination. ${ }^{12}$ This procedure, therefore, gives a good approximation of electroactive metal fraction, which is based on the deposition procedure of labile concentration for metals at the surface of electrode approximating to the kinetics of their uptake processes by cells of organisms as closely as possible. ${ }^{13,14}$ The correlation between ASV-labile concentrations of $\mathrm{Cu}$ and its toxicity derived from bioassay may be, therefore, useful in prediction its speciation/toxicity relationship. Unfortunately, this relationship can hardly predict the influences of alkalinity and hardness on the toxicity of $\mathrm{Cu}$ in natural waters. Some aquatic components, such as fulvic acid (FA), can affect the stripping current not only through changes in aqueous $\mathrm{Cu}$ speciation, but also through adsorption of organic components on the surface of electrode (e.g. mercury drop). To avoid the interferences of organic components on stripping current, a double acidification method (DAM) is recommended. ${ }^{15}$ Strong organic complexes of $\mathrm{Cu}$ (e.g. Cu-EDTA, Cu-FA) are neither labile nor bioavailable to acute toxicity, ${ }^{1,14}$ the labile concentration of $\mathrm{Cu}$ should be contributed mainly by inorganic species and only some inorganic species are bioavailabile or are toxic forms. Therefore, it is possible to exclude the influences of $\mathrm{Cu}$-carbonates and $\mathrm{Cu}$-chlorides from the measured labile concentration and use a defined term, i.e. $\left[\mathrm{Cu}^{*}\right]$, to predict the toxicity of $\mathrm{Cu}$ in a complex system. ${ }^{16}$ In the study, this hypothesis was tested by $\mathrm{Cu}$-spiking lake water and bioassay using luminescent bacterium -Q67.

The obvious disadvantage of traditional Microtox ${ }^{\circledR}$ is that it required $2 \% \mathrm{NaCl}$ in medium to maintain luminescent bacterium bioassay. Vibrio-qinghaiensisNov.$Q 67$ was a new species freshwater luminescent bacterium isolated from the body surface of Cymnocypris przewalyskii, an edible fish in Qinghai province of China. ${ }^{17,18}$ This type of freshwater luminescent bacterium may be natural luminous in freshwater with low concentration of sodium, and eliminated effects of chloride on the metal toxicity index and speciation. Q67 could be used to evaluate the relationship between metals speciation and metals toxicity. In this paper, differential pulse anodic stripping voltammetry measurement combined with a double acidification method (DAM-DPASV) was performed to obtain the labile concentration of $\mathrm{Cu}$ and bioassay using $Q 67$ was performed to obtain the acute toxicity, both in test solution and in spiked natural water samples.

\section{METHODOLOGY}

\section{Sampling preparation}

The natural water samples were taken in Guanting Reservoir in Northwest, city of Beijing, China. The sampling sites are illustrated in Figure 1. Twenty liters of water sample was filtered through Millipore $0.45 \mu \mathrm{m}$ filter and collected in a pre-cleaned polyethylene bottle. After sampling, concentration of dissolved organic carbon (DOC) was measured by high-temperature combustion method on a TOC meter (Phoenix 8000, Tekmar-Dohrmann, OH., USA). Major anions were measured by ion chromatography (Model 4500i, Dionex, CA, USA). The total concentration of dissolved metals in water samples were measured in acidified filtrates by graphite furnace atomic absorption spectrometry (GFAAS, PerkinElmer 3100, Conn., USA)

A stock solution of $\mathrm{Cu}$ was prepared in doubledistilled deionized water $\left(\mathrm{bddH}_{2} \mathrm{O}\right)$ from analytical reagent $\left(\mathrm{CuSO}_{4} \cdot 7 \mathrm{H}_{2} \mathrm{O}\right)$, acidified to $10^{-4} \mathrm{~mol} \mathrm{~L}^{-1} \mathrm{HNO}_{3}$. Copper was sequentially spiked from the stock solution of $\mathrm{Cu}$ to the filtered water samples to a final concentration of $0.89 \mathrm{mg} \mathrm{L}^{-1}$ in seven increments. The spiked samples were stored in $4^{\circ} \mathrm{C}$ and used in a week.

\section{Test solution preparation}

The test solution used for the study of the influences of different aquatic components on $\mathrm{Cu}$ speciation and toxicity was prepared by diluting the stock solution of $\mathrm{Cu}$ with reconstituted water. ${ }^{19}$ The test solutions of different alkalinity, or containing different amount of $\mathrm{NaCl}$, EDTA, and FA were prepared by adding appropriate amounts of stocks of $\mathrm{NaHCO}_{3}, \mathrm{NaCl}$, Na-EDTA and FA to the reconstituted water. The test solution was buffered with $\mathrm{N}$-[2-Hydroxyethyl]-piperazine-N' [2-ethanesulfonic acid] (HEPES, Sino-American Biotec, Beijing) and the $\mathrm{pH}$ was adjusted with $0.5 \mathrm{~mol}$ $\mathrm{L}^{-1} \mathrm{NaOH}$ to 6.8 prior to use. It has been demonstrated that HEPES at $<0.01 \mathrm{~mol} \mathrm{~L}^{-1}$ does not significantly bind metals. ${ }^{20}$ The test solution was spiked with different doses of $\mathrm{Cu}$ and allowed to equilibrate for at least 24 hours at a constant temperature of $23 \pm 1^{\circ} \mathrm{C}$ before DAM-DPASV measurements and bioassays. In the experiments, FA was extracted and separated from sediment of Guanting Reservoir and purified following the method described earlier. ${ }^{21}$ Concentrations of FA (in units of $\mathrm{mg} \mathrm{L}^{-1} \mathrm{DOC}$ ) in the stock solutions were measured after filtering stock solutions of FA through $0.45 \mu \mathrm{m}$ membrane filters by high-temperature combustion (Phoenix 8000, Tekmar-Dohrmann, OH, USA). 


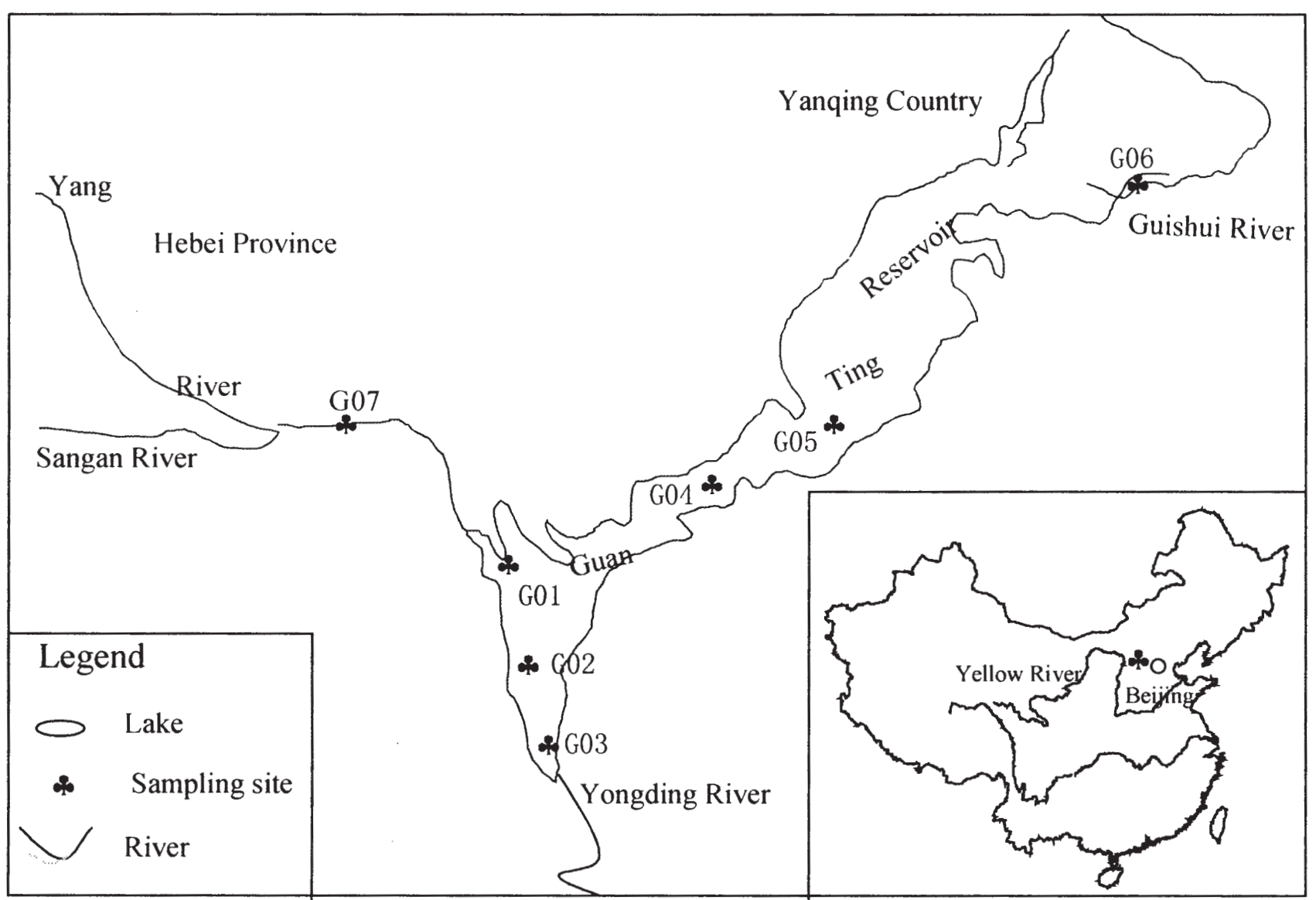

Figure 1 Schematic illustration of research area and sampling sites

\section{Measurements of the total and labile concentrations of $\mathrm{Cu}$}

In the voltammetry measurements, the mercury electrode as the working electrode was washed with $10 \%$ nitric acid and bdd $\mathrm{H}_{2} \mathrm{O}$ twice. To avoid metal contamination, all glass and plastic ware were washed with 1:1 nitric acid followed by bdd $\mathrm{H}_{2} \mathrm{O}$. In all experiments, a $0.1 \mathrm{~mol} \mathrm{~L}^{-1}$ sodium nitrate was used to maintain ion strength in working solutions. Measurements were carried out in $10 \mathrm{~mL}$ working solution in a cell at $23 \pm 1^{\circ} \mathrm{C}$. The instrument consisted of an EG \& G Princeton applied Research Model 263 polarographic analyzer, with a Model 303 static mercury drop electrode assembly plus a mode 303 stirrer(EG\&G, NJ, USA). The specific setting used for the differential pulse mode was: scan rate of $10 \mathrm{mV} \mathrm{s}^{-1}$; drop size, medium; pulse height of $50 \mathrm{mV}$; step time of $0.3 \mathrm{~s}$; and scan width of $2 \mathrm{mV}$; initial potential, $-1.0 \mathrm{~V}$; final potential, $+0.15 \mathrm{~V}$ versus $\mathrm{Ag}-\mathrm{AgCl}$. Arotation rate of $4000 \mathrm{rpm}$ was used. During each step of the titration, the electrode surface was wiped clean with plain filter paper and rinsed with bdd $\mathrm{H}_{2} \mathrm{O} .10 \mathrm{~mL}$ aliquots of sample were transferred to acid-cleaned polarographic cell. Then, the sample were degassed with oxygen-free $\mathrm{N}_{2}$ for $5 \mathrm{~min}$. Samples were plated at $-0.6 \mathrm{~V}$ for $300 \mathrm{~s}$, follow by a $15 \mathrm{~s}$ quiescent period before the film was stripped by scanning the potential in the positive direction, using the differential pulse mode, to a final potential of $+0.15 \mathrm{~V}$. The double acidification procedure involved a deposition at $\mathrm{pH}$ 6.8, then, $20 \mathrm{~s}$ before completion of the $300 \mathrm{~s}$ deposition, and with the cell circuit uninterrupted, $50 \mu \mathrm{l}$ of $5 \mathrm{~mol} \mathrm{~L}^{-1}$ $\mathrm{HNO}_{3}$ were added through the standard addition port to the cell. After recording the stripping voltammogram, a new run was initiated for the same solution; this time the $\mathrm{pH}$ during both deposition and striping run was below $\mathrm{pH}$ 2.0. The percentage of labile $\mathrm{Cu}$ in the total $\mathrm{Cu}$ could be obtained from:

$$
\text { Labile-Cu }(\%)=100\left[1-\left(c_{1}-c_{2}\right) / c_{\mathrm{T}}\right]
$$

Where $c_{1}$ is concentrations of $\mathrm{Cu}$ measured with deposition and stripping at $\mathrm{pH}=2, c_{2}$ is that deposition at $\mathrm{pH}$ 6.8 and stripping at $\mathrm{pH} 2$, and $c_{\mathrm{T}}$ is the total $\mathrm{Cu}$ concentration, respectively. ${ }^{15}$ The calibration was carried out in $\mathrm{Cu}$ concentrations range of $0.5-20 \mu \mathrm{g} \mathrm{L}^{-1}$ in 10 increments in reconstituted water (including $0.1 \mathrm{~mol} \mathrm{~L}^{-1}$ $\left.\mathrm{NaNO}_{3}, 0.006 \mathrm{~mol} \mathrm{~L}^{-1} \mathrm{HEPES}\right)$. For each sample, triplicates were measured and the labile concentration of $\mathrm{Cu}$ was calculated from calibration. Precision for measurements in DAM-DPASV was $\pm 9 \%$ (RSD) for test 
solution containing $2 \mu \mathrm{g} \mathrm{Cu} \mathrm{L}-1(n=6)$.

Total dissolved $\mathrm{Cu}$ in natural water samples was measured in acidified filtrates by graphite furnace atomic absorption spectrometry (GFAAS, Perking Elmer 3100,USA).

\section{Q67 bioassay}

The culture medium for $Q 67$ consisted of $13.6 \mathrm{mg}$ $\mathrm{KH}_{2} \mathrm{PO}_{4}, \quad 35.8 \mathrm{mg} \quad \mathrm{Na}_{2} \mathrm{HPO}_{4} .12 \mathrm{H}_{2} \mathrm{O}, \quad 0.25 \mathrm{~g}$ $\mathrm{MgSO}_{4} \cdot 7 \mathrm{H}_{2} \mathrm{O}, 0.61 \mathrm{~g} \mathrm{MgCl}_{2} \cdot 6 \mathrm{H}_{2} \mathrm{O}, 33.0 \mathrm{mg} \mathrm{CaCl}$, $1.34 \mathrm{~g} \mathrm{NaHCO}_{3}, 1.54 \mathrm{~g} \mathrm{NaCl}, 5.0 \mathrm{~g}$ yeast extract, $5.0 \mathrm{~g}$ tryptone, $3.0 \mathrm{~g}$ glycerin and $1000 \mathrm{~mL}$ distilled water. Before each test, the bacterium was inoculated from a stock culture, which is maintained on Q67 culture medium agar at $4^{\circ} \mathrm{C}$, to a fresh agar and cultured at $23 \pm 1^{\circ} \mathrm{C}$ for 24 hours. The cells were further grown in liquid culture medium by shaking $(120 \mathrm{rpm})$ at $23 \pm 1^{\circ} \mathrm{C}$ for 14 hours and harvested by centrifuge at $3000 \mathrm{rpm}$ for $10 \mathrm{~min}$. The pellet was washed, centrifuged twice, as well as suspended in test medium. The RLU in Q67 suspension was adjust to 1.0-2.5 million with test medium and the suspension was kept at $23 \pm 1{ }^{\circ} \mathrm{C}$ for 20 min before bioassay.

The bioassays were carried out by adding $0.1 \mathrm{~mL}$ bacterial suspension and $0.9 \mathrm{~mL}$ test solutions to a plastic tube (low-background tube from Berthod Company), thoroughly mixed and the initial relative light unit (RLU) was recorded by a illuminometers (Berthod LB9501, Germany). After 20 min incubation at $23 \pm 1{ }^{\circ} \mathrm{C}$, the final RLU was recorded. Seven concentrations gradients were used for obtaining the doseeffect relationship and $\mathrm{EC}_{50} \mathrm{~S}$ of copper in the test solutions and spiked natural waters were calculated from the plot of $\log \Lambda v s \log$ (concentration), where $\Lambda$ is defined as the ratio of amount of light loss during incubation time to the amount of light remaining $\mathrm{EC}_{50}$ corresponds to $\Lambda=1 .^{22}$ Toxic probit was transformed from mortality following the method of probit unit. ${ }^{23}$ Regression analysis was performed using Sigmaplot ${ }^{\circledR}$ 4.0 (SPSS, Chicago, IL, USA).

\section{Cu speciation}

The concentrations of different $\mathrm{Cu}$ species presented in test solutions, other than that containing FA, could be calculated from the spiked concentrations of $\mathrm{Cu}$, the composition of the reconstituted water, as well as the known stability constants of $\mathrm{Cu}$ complexes, using MINTEQ A2 (ver4.1, US EPA). For water samples and test solution containing $\mathrm{FA}$, inorganic $\mathrm{Cu}$ speciation can be calculated from labile concentration of $\mathrm{Cu}$, assuming that $\mathrm{Cu}$ associated with strong organic ligands was non-labile in DPASV measurements and $\mathrm{Cu}$ associated with weak organic ligands was negligible in comparison to inorganic complexes of similar stability constants. This hypothesis is valid because DPASV has long been used to obtain the apparent stability constants of $\mathrm{Cu}$ with $\mathrm{FA}$, both by metal titration and proton titration. ${ }^{12,24}$

By DAM-DPASV measurements, complexation capacity of $\mathrm{Cu}$ in Guanting Reservoir waters could be determined following the method described earlier. ${ }^{25}$

\section{RESULTS AND DISCUSSION}

\section{Deriving the expression for the relationship between $\mathrm{Cu}$ speciation and acute toxicity}

Influences of different anions on acute toxicity of metals to $Q 67$ have been screened in the experiments. Influences of alkalinity (expressed as $\mathrm{HCO}_{3}{ }^{-}$), different concentrations of chloride, EDTA as well as FA (expressed as DOC) on the toxicity of $\mathrm{Cu}$ are shown in Figure 2. The toxicity increased with spiked concentrations of $\mathrm{Cu}$ and decreased with spiked concentrations of carbonate, chloride, EDTA and FA, respectively. Similar observations were reported in previous works for organisms other than luminescent bacteria. ${ }^{14}$

The results could be explained with FIAM that the consequence of complexation of $\mathrm{Cu}$ with $\mathrm{HCO}_{3}{ }^{-}, \mathrm{Cl}^{-}$, EDTA and DOC was the reduction in free ion activity in the aqueous phase and thus reduced the potential of metal uptake by organisms.

The results could be equally explained as the consequences of formation of non-bioavailable or non-toxic species, such as $\mathrm{Cu}-\mathrm{HCO}_{3}, \mathrm{Cu}-\mathrm{Cl}, \mathrm{Cu}-\mathrm{EDTA}$ and $\mathrm{Cu}-\mathrm{DOC}$.

When $\mathrm{NaHCO}_{3}$ was spiked into the reconstituted water (Figure 2a), the dominant species of $\mathrm{Cu}$ are $\mathrm{Cu}^{2+}$, $\mathrm{CuOH}^{+}, \mathrm{Cu}(\mathrm{OH})_{2} \mathrm{aq}, \mathrm{CuCO}_{3} \mathrm{aq}$, and $\mathrm{CuHCO}_{3}{ }^{+}$. Under constant $\mathrm{pH}$, the decrease of toxicity correlates well with the increase of $\mathrm{CuCO}_{3}$ aq and $\mathrm{CuHCO}_{3}{ }^{+}$. The linear regression between $\mathrm{EC}_{50}\left(\mathrm{mg} \mathrm{L}^{-1}\right)$ and concentration of $\mathrm{HCO}_{3}^{-}\left(\mathrm{mg} \mathrm{L}^{-1}\right)$ could be expressed as:

$$
\mathrm{EC}_{50}\left(\mathrm{mg} \mathrm{L}^{-1}\right)=0.0034\left[\mathrm{HCO}_{3}^{-}, \mathrm{mg} \mathrm{L}^{-1}\right]+
$$$$
0.1801\left(R^{2}=0.9513, n=7\right)
$$

The toxicity of copper was significantly reduced when the concentration of chloride in aqueous phase is higher than $99.4 \mathrm{mg} \mathrm{L}^{-1}$ (Figure $2 \mathrm{~b}$ ) and the decrease of toxicity correlates well with the increase of concentrations of $\mathrm{CuCl}_{n}{ }^{-(n-2)}$. The linear regression between $\mathrm{EC}_{50}$ $\left(\mathrm{mg} \mathrm{L}^{-1}\right)$ and concentration of chloride $\left(\mathrm{mg} \mathrm{L}^{-1}\right)$ could be expressed as:

$\mathrm{EC}_{50}\left(\mathrm{mg} \mathrm{L}^{-1}\right)=0.0002\left[\mathrm{Cl}^{-}, \mathrm{mg} \mathrm{L}^{-1}\right]+0.1914$

$\left(R^{2}=0.8584, n=8\right)$

By classification analysis, $\mathrm{CuCl}_{\mathrm{n}}{ }^{-(\mathrm{n}-2)}$ complexes could be classified as non-toxic forms. Sarin et al. ${ }^{26}$ have shown in their recent publication that the toxicity of $\mathrm{Cu}$ was a function of $\mathrm{Cl}^{-}$concentration. The toxicity of $\mathrm{Cu}$ decreased at high $\mathrm{Cl}^{-}$concentrations as free $\mathrm{Cu}^{2+}$ 

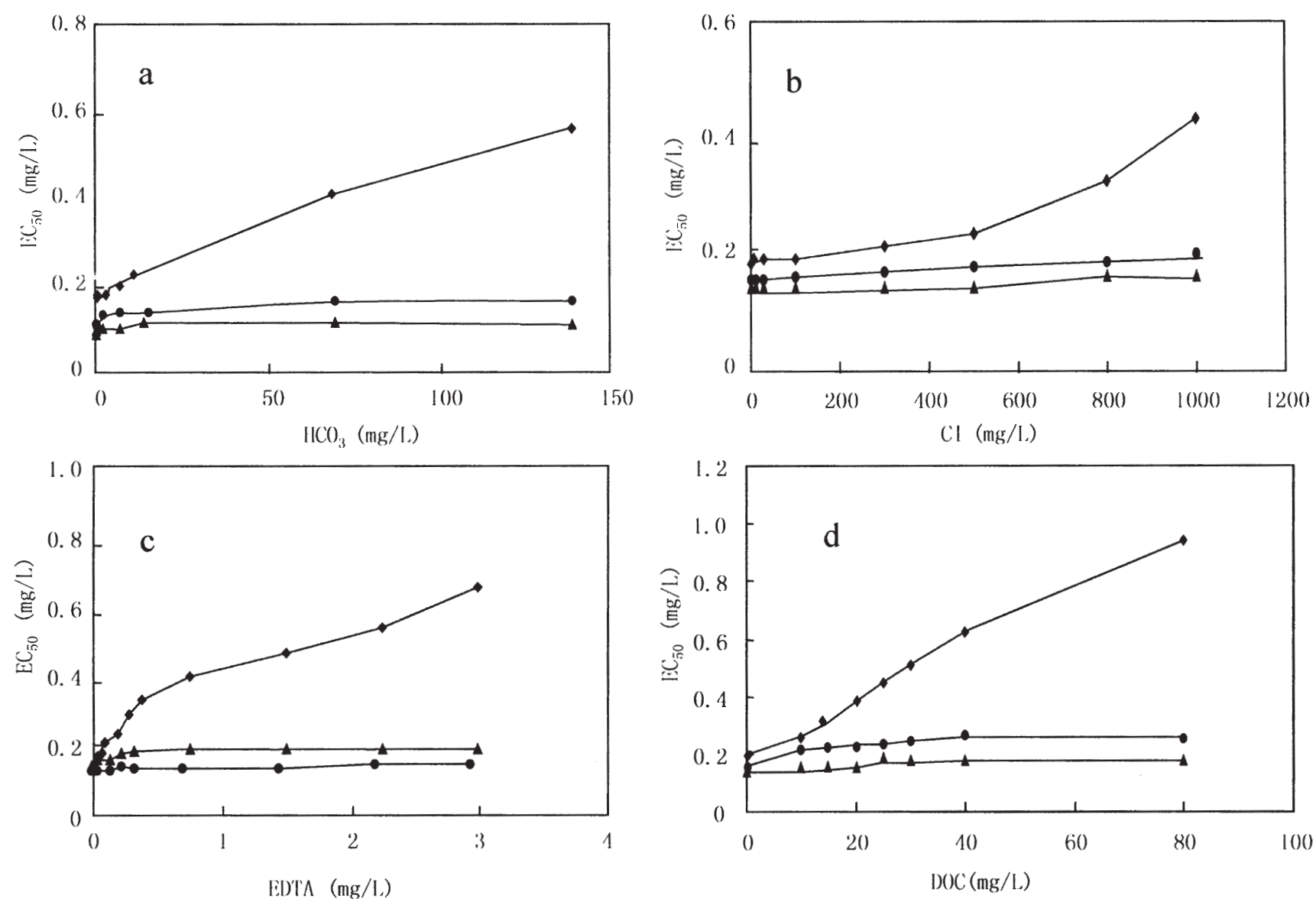

Figure 2 Variation in $E C_{50}$ expressed by different copper speciation as a function of ligand concentration. Copper

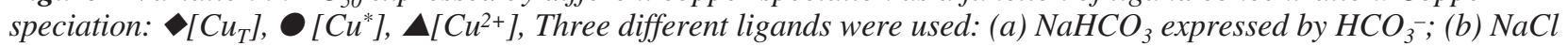
expressed by $\mathrm{Cl}^{-}$; (c) EDTA; (d) FA expressed by DOC.

decreased, in accordance with the free ion model (FIAM). Our results support their findings and support that the toxicity reduction could be explained as the consequence of formation of non-toxic chemical forms.

When EDTA was spiked into the reconstituted water (Figure 2c), the dominant species of $\mathrm{Cu}$ are $\mathrm{Cu}$-EDTA complexes. When the molar concentration of EDTA is larger than that of $\mathrm{Cu}, \mathrm{Cu}$ species other than $\mathrm{Cu}^{2+}$ and $\mathrm{Cu}-\mathrm{EDTA}$ could be negligible. Under constant $\mathrm{pH}$ and alkalinity, the decrease in toxicity should be due to the increase in concentration of Cu-EDTA. The linear regression between $\mathrm{EC}_{50}\left(\mathrm{mg} \mathrm{L}^{-1}\right)$ and concentration of EDTA ( $\left.\mathrm{mg} \mathrm{L}^{-1}\right)$ could be expressed as:

$\mathrm{EC}_{50}\left(\mathrm{mg} \mathrm{L}^{-1}\right)=0.1468$ [EDTA, $\left.\mathrm{mg} \mathrm{L}^{-1}\right]+0.1731$

$\left(R^{2}=0.9752, n=10\right)$

When FA was spiked into the reconstituted water (Figure $2 \mathrm{~d}$ ), the dominant species of $\mathrm{Cu}$ should turn to be $\mathrm{Cu}$-DOC complexes. $\mathrm{Cu}$ species other than $\mathrm{Cu}-\mathrm{DOC}$ decreased significantly. The decrease in toxicity should be due to the increase in concentration of $\mathrm{Cu}-\mathrm{DOC}$ or decrease of free ion concentration of $\mathrm{Cu}$. The linear regression between $\mathrm{EC}_{50}\left(\mathrm{mg} \mathrm{L}^{-1}\right)$ and concentration of FA (expressed as DOC, $\mathrm{mg} \mathrm{L}^{-1}$ ) could be expressed as:

$\mathrm{EC}_{50}\left(\mathrm{mg} \mathrm{L}^{-1}\right)=0.0093\left[\mathrm{DOC}, \mathrm{mg} \mathrm{L}^{-1}\right]+0.1849$

$\left(R^{2}=0.9637, n=8\right)$

In order to study the influences of multi-components on toxicity of $\mathrm{Cu}$, an orthogonal experiment was designed in which $\mathrm{EC}_{50} \mathrm{~s}$ under different concentrations of $\mathrm{NaHCO}_{3}$, chloride, EDTA and FA were obtained. By multiregression analysis, the relationship between $\mathrm{EC}_{50}$ and concentrations of $\mathrm{HCO}_{3}^{-}, \mathrm{Cl}^{-}$, EDTA and DOC could be expressed as:

$\mathrm{EC}_{50}\left(\mathrm{mg} \mathrm{L}^{-1}\right)=0.191+0.111\left[\right.$ EDTA, $\left.\mathrm{mg} \mathrm{L}^{-1}\right]+$ $0.031\left[\mathrm{Cl}^{-}, \mathrm{mg} \mathrm{L}^{-1}\right]+0.012\left[\mathrm{HCO}_{3}^{-}, \mathrm{mg} \mathrm{L}^{-1}\right]+$ 0.158 [DOC, $\mathrm{mg} \mathrm{L}^{-1}$ ]

It is interesting to note that the interrupts in the empirical equations of (1) through (4) were in a relatively narrow range, i.e., from 0.17 to $0.19 \mathrm{mg} \mathrm{L}^{-1}$. This value is very close to the $\mathrm{EC}_{50} 0.19 \mathrm{mg} \mathrm{L}^{-1}$ of media in absence of complexing ligands in reconstituted water 
in Eqn (5). The coefficients in Eqn (5) could be used to value the importance of each complexing ligand and show that FA has much stronger influence on $\mathrm{Cu}$ toxicity to $Q 67$ than that of alkalinity, chloride and EDTA. It is clear that the influence of FA on toxicity is 13 times higher than that of alkalinity.

In our hypothesis, only part of inorganic $\mathrm{Cu}$ species contributes to the toxicity. Therefore, we can define a bioavailable concentration of $\mathrm{Cu}$ (or $\left[\mathrm{Cu}^{*}\right]$ ) to denote the sum of inorganic species other than $\mathrm{Cu}$-carbonate complexes and $\mathrm{Cu}$-chloride complexes. Therefore the intercepts in Eqns (1)-(5) represent the bioavailable concentration of $\mathrm{Cu}$ in solutions of different compositions that causes the $50 \%$ amount of light loss or $\mathrm{EC}_{50}$. In Figure 2, the $\mathrm{EC}_{50} \mathrm{~s}$ of $\mathrm{Cu}$ in presence of carbonate, chloride, EDTA and FA were expressed as function of $\left[\mathrm{Cu}_{\mathrm{T}}\right],\left[\mathrm{Cu}^{2+}\right]$ and $\left[\mathrm{Cu}^{*}\right]$, respectively. The expressions of $\mathrm{EC}_{50} \mathrm{~s}$ in terms of either $\left[\mathrm{Cu}^{2+}\right]$ or $\left[\mathrm{Cu}^{*}\right]$ resulted in a constant value, which was independent of variation in ligands concentrations. In fact, the percentile distribution among inorganic $\mathrm{Cu}$ species is not affected by the presence of organic components, and the concentration of $\left[\mathrm{Cu}^{2+}\right]$ is proportional to the concentration of $\left[\mathrm{Cu}^{*}\right]$ if the composition of anions and cations in the solution is constant. The results indicated that the $\mathrm{EC}_{50}$ data could either explained by FIAM or by the hypothesis that only bioavailable or toxic fraction of $\mathrm{Cu}\left[\mathrm{Cu}^{*}\right]$ in solution could be responsible for the observed toxicity.

The difficulty in using FIAM to predict $\mathrm{Cu}$ toxicity in natural water is the determination of the site-specific apparent complexation constant for the complex of $\mathrm{Cu}$ and DOC (or FA). Therefore we may use [Cu*] to predict the acute toxicity of $\mathrm{Cu}$ on $Q 67$. This approach is similar to that using inorganic concentrations of $\mathrm{Cu}$ to predict the acute toxicity, ${ }^{2}$ but it took into the account that part of inorganic $\mathrm{Cu}$ species may not contribute to the toxicity. In practice, the labile concentration of $\mathrm{Cu}$ was calculated from the stripping current in DAM-DPASV measurements. The bioavailable concentration of $\mathrm{Cu}$, or $\left[\mathrm{Cu}^{*}\right]$, could be obtained from a model calculation, assuming that the labile metal comprised of inorganic species.

In natural water, an acute toxicity exceeding $\mathrm{EC}_{50}$ could hardly be observed, Therefore, the toxic data obtained in simulation experiments with different concentrations of $\mathrm{NaHCO}_{3} \mathrm{NaCl}$, EDTA and FA, excepting percentage of inhibition were less than $10 \%$ or higher than $90 \%$, were transformed into toxic probit (TP) and plotted versus [Cu*] $\left(\mathrm{mg} \mathrm{L}^{-1}\right)$, as shown in Figure 3. The regression equation was shown as follows, which would be used in predicting $\mathrm{Cu}$ toxicity in natural water for amount of light loss equals $50 \%$.

$\mathrm{TP}=15.55\left[\mathrm{Cu}^{*}\right]\left(\mathrm{mg} \mathrm{L}^{-1}\right)+3.73$

$\left(R^{2}=0.7566, n=29\right)$

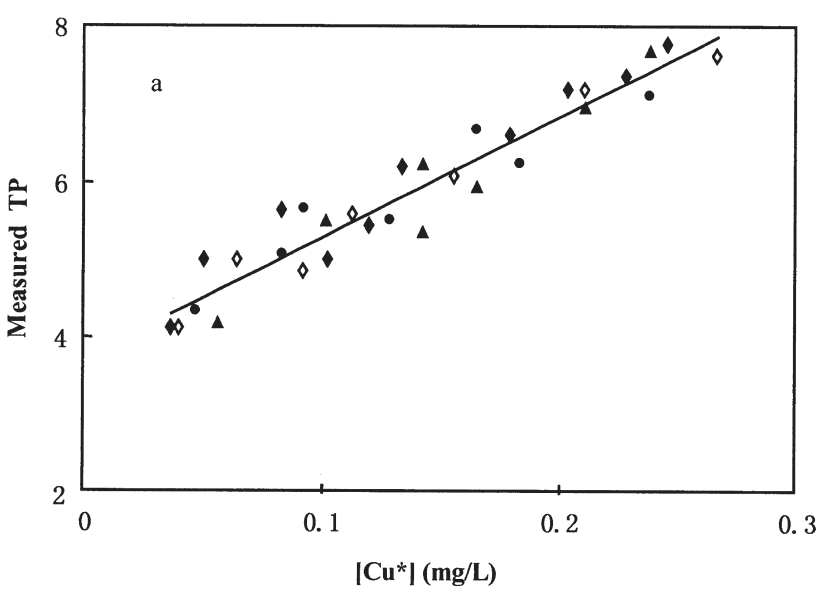

Figure 3 Relationship between measured TP by bioassays and calculated logarithm $\left[\mathrm{Cu}^{*}\right]\left(\diamond \mathrm{HCO}_{3}^{-} ; \mathrm{Cl}^{-}\right.$;

$\triangle D O C ; \diamond E D T A)$. In the figure, toxic data $(\mathrm{n}=31)$ were from Figure 2.

\section{Measuring water quality parameters and $\mathrm{cu}$ toxicity in Guanting reservoir waters}

A case study was carried out in Guanting Reservoir in Beijing. After sampling, cations, anions and other water quality parameters, such as $\mathrm{pH}$ and concentrations of DOC, are shown in Table 1. The major metals were measured and the results are shown in Table 2.

In most of the natural freshwaters, $\mathrm{Cu}$ was mainly bound to organic substances. ${ }^{13}$ Because of the presence of natural derived organic matters and surfactants, the stripping current in the ASV measurements were frequently interfered. A double acidification procedure was, therefore, introduced to eliminate the effects of complexing agents on the ASV stripping process and of surfactants on both deposition and stripping processes in natural water. ${ }^{14}$ The labile concentration of $\mathrm{Cu}$ was calculated from the measured stripping current in DAM-DPASV measurements. The concentration of $\left[\mathrm{Cu}^{*}\right]$ was calculated by assuming that the labile metal was inorganic species.

Concentrations of different $\mathrm{Cu}$ species and complexation capacity and predicted/measured toxicity to Q67 in Guanting Reservoir waters were illustrated in Table 3. The highest concentration of dissolved copper was $8.88 \mu \mathrm{g} \mathrm{L}^{-1}$ at site $\mathrm{G} 03$, which was lower than the allowable levels (GHZB-1-1999).27 However, both the highest labile concentration or bioavailable concentration of $\mathrm{Cu}$ occurred at G07 $\left(5.3 \mu \mathrm{g} \mathrm{L}^{-1}\right.$ and $0.54 \mu \mathrm{g} \mathrm{L}-1$, respectively). In comparison between G03 and G07, the lability and bioavailability of $\mathrm{Cu}$ was affected by concentration of DOC (Table 1), which could bind $\mathrm{Cu}$ in its matrix (Table 3 ).

At sites G03 and G07, measured inhibitions on Q67 were not observed, while the amount of light loss of $3 \%$ and $7 \%$ were predicted using Eqn (6). A light loss 


\begin{tabular}{|c|c|c|c|c|c|c|c|c|c|c|c|}
\hline Sampling sites & Locations & $\mathrm{pH}$ & DOC & $\mathrm{HCO}_{3}^{-}$ & $\mathrm{Cl}^{-}$ & $\mathrm{NO}_{3}^{-}$ & $\mathrm{SO}_{4}{ }^{2-}$ & $\mathrm{Na}^{+}$ & $\mathrm{K}^{+}$ & $\mathrm{Mg}^{2+}$ & $\mathrm{Ca}^{2+}$ \\
\hline G01 & $40\left(18^{\prime} 02^{\prime \prime} \mathrm{N}, 115\left(37^{\prime} 37^{\prime \prime} \mathrm{E}\right.\right.$ & 8.5 & 0.6 & 0.73 & 3.1 & 5.2 & 76.2 & 5.5 & 0.3 & 4.0 & 12.5 \\
\hline G02 & 40(16'11'’N, 115(37'37''E & 8.4 & 1.4 & 0.74 & 4.7 & 9.2 & 88.8 & 4.3 & 0.3 & 3.2 & 12.5 \\
\hline G03 & $40\left(15^{\prime} 07^{\prime \prime} \mathrm{N}, 115\left(36^{\prime} 09^{\prime \prime} \mathrm{E}\right.\right.$ & 8.5 & 1.2 & 0.69 & 2.3 & 5.4 & 78.2 & 4.7 & 0.3 & 4.2 & 11.8 \\
\hline G04 & $40\left(20^{\prime} 41^{\prime \prime} \mathrm{N}, 115\left(42^{\prime} 52^{\prime \prime} \mathrm{E}\right.\right.$ & 8.5 & 1.5 & 0.54 & 3.5 & 8.7 & 87.5 & 5.0 & 0.4 & 3.3 & 10.4 \\
\hline G05 & $40\left(21^{\prime} 44^{\prime \prime} \mathrm{N}, 115\left(45^{\prime} 39^{\prime \prime} \mathrm{E}\right.\right.$ & 8.2 & 1.2 & 0.71 & 2.8 & 4.8 & 74.4 & 4.8 & 0.5 & 4.4 & 11.2 \\
\hline G06 & 40(27'16'”N, 115(59'34'’E & 8.4 & 2.4 & 0.73 & 4.1 & 6.4 & 69.4 & 5.3 & 0.4 & 5.0 & 11.0 \\
\hline G07 & $40\left(21^{\prime} 20^{\prime \prime} \mathrm{N}, 115\left(31^{\prime} 46{ }^{\prime \prime} \mathrm{E}\right.\right.$ & 8.1 & 0.2 & 0.75 & 2.9 & 5.8 & 76.5 & 4.5 & 0.4 & 5.0 & 16.6 \\
\hline
\end{tabular}

Table 2 Concentrations of main metals and non-metals of water samples in Guanting Reservoir $\left(\mu \mathrm{g} \mathrm{L}^{-1}\right)$

\begin{tabular}{llllllllll}
\hline Sampling sites & $\mathrm{Cr}$ & $\mathrm{Mn}$ & $\mathrm{Co}$ & $\mathrm{Ni}$ & $\mathrm{Zn}$ & $\mathrm{Cu}$ & $\mathrm{Mo}$ & $\mathrm{Cd}$ & $\mathrm{Pb}$ \\
\hline G01 & 6.8 & 0.67 & 0.27 & 2.67 & 12.14 & 2.67 & 6.06 & 0.1 & 1.0 \\
G02 & 6.3 & 0.93 & 0.35 & 3.12 & 19.20 & 2.67 & 7.56 & 0.1 & 1.9 \\
G03 & 4.8 & 1.20 & 0.54 & 3.94 & 14.51 & 8.88 & 7.68 & 0.1 & 17.6 \\
G04 & 8.8 & 1.05 & 0.38 & 4.39 & 22.95 & 5.47 & 6.71 & 0.7 & 7.7 \\
G05 & 3.6 & 0.91 & 0.35 & 2.56 & 9.09 & 2.06 & 2.81 & 0.1 & 3.7 \\
G06 & 3.2 & 1.48 & 0.51 & 3.67 & 13.19 & 4.62 & 2.91 & 0.1 & 0.7 \\
G07 & 4.2 & 0.46 & 0.43 & 2.64 & 12.19 & 6.21 & 5.76 & 0.1 & 1.1 \\
\hline
\end{tabular}

Table 3 Concentrations of various $\mathrm{Cu}$ speciation and predicted/measured inhibition to $Q 67$ in Guanting Reservoir waters

\begin{tabular}{llllllll}
\hline & G01 & G02 & G03 & G04 & G05 & G06 & G07 \\
\hline$\left[\mathrm{Cu}_{\mathrm{T}}\right]\left(\mu \mathrm{g} \mathrm{L}^{-1}\right)^{\mathrm{a}}$ & 2.7 & 2.7 & 8.9 & 5.4 & 2.1 & 4.6 & 6.2 \\
{$\left[\mathrm{Cu}_{\text {labile }}\right]\left(\mu \mathrm{g} \mathrm{L}^{-1}\right)^{\mathrm{b}}$} & $\mathrm{ND}$ & $\mathrm{ND}$ & $4.4 \pm 1.3$ & $2.1 \pm 0.7$ & $1.3 \pm 1.1$ & $1.1 \pm 0.9$ & $5.3 \pm 0.9$ \\
{$\left[\mathrm{Cu}^{*}\right]\left(\mu \mathrm{g} \mathrm{L}^{-1}\right)^{\mathrm{c}}$} & $\mathrm{ND}$ & $\mathrm{ND}$ & 0.26 & 0.11 & 0.08 & 0.12 & 0.54 \\
${\text { Measured inhibition }(\%)^{\mathrm{d}}}^{\mathrm{d}}$ & $\mathrm{ND}$ & $\mathrm{ND}$ & $\mathrm{ND}$ & $\mathrm{ND}$ & $\mathrm{ND}$ & 28 & ND \\
Predicted inhibition $(\%)^{\mathrm{e}}$ & $\mathrm{ND}$ & $\mathrm{ND}$ & 3 & $\mathrm{ND}$ & $\mathrm{ND}$ & $\mathrm{ND}$ & 7 \\
$\mathrm{CC}\left(\mu \mathrm{g} \mathrm{L}^{-1}\right)^{\mathrm{f}}$ & $34 \pm 21$ & $64 \pm 17$ & $31 \pm 15$ & $85 \pm 24$ & $26 \pm 15$ & $128 \pm 57$ & $53 \pm 34$ \\
\hline
\end{tabular}

aThe $\left[\mathrm{Cu}_{\mathrm{T}}\right]$ was measured by using GFASS.

bThe $\left[\mathrm{Cu}_{\text {labile }}\right]$ was measured by using DAM-DPASV.

cThe $\left[\mathrm{Cu}^{*}\right]$ was calculated from $\left[\mathrm{Cu}_{\text {labile }}\right]$ and concentration of anions in water using MINTEQA2.

dThe percentage of inhibition was measured on $Q 67$.

eThe percentage of inhibition was predicted on $Q 67$ using Eqn (6) through inhibition/toxic probit conversion table.

${ }_{\mathrm{f}} \mathrm{CC}=$ Complexation capacity of natural water measured by DAM-DPASV.

ND $=$ Not detected.

of less than $10 \%$ was considered as insignificant (confidence interval 90\%). At other sites except for G06, light loss could be neither measured nor predicted. The measured amount of light loss (28\%) at site G06 was probably caused by toxicants other than $\mathrm{Cu} .{ }^{28}$ The predicted light loss by bioavailable concentration of $\mathrm{Cu}$ using Eqn (5) was quite consistent with the measured light loss using bioassays for Guanting reservoir.

To test the hypothesis, the water samples from Guanting Reservoir were spiked with stock solution of $\mathrm{Cu}$ and $\mathrm{EC}_{50} \mathrm{~s}$ were obtained. The spiked solution was then subjected to DAM-DPASV measurements to obtain labile concentrations of $\mathrm{Cu}$ in the spiked waters. Accordingly, concentrations of bioavailable $\mathrm{Cu}\left(\left[\mathrm{Cu}^{*}\right]\right)$ were calculated using MINTEQ A2.
In Figure 4, the observed $\mathrm{EC}_{50} \mathrm{~s}$ were expressed in terms of total $\mathrm{Cu}$ concentration, the labile $\mathrm{Cu}$ concentration, concentration of free $\mathrm{Cu}$ ion, as well as the bioavailable concentration of $\mathrm{Cu}$. When expressed as total $\mathrm{Cu}$ concentration, $\mathrm{EC}_{50}$ varies with sampling sites in the range of $0.25-0.35 \mathrm{mg} \mathrm{L}^{-1}$. When expressed as labile concentration, $\mathrm{EC}_{50} \mathrm{~s}$ were in the range of $0.17-0.23 \mathrm{mg} \mathrm{L}^{-1}$. While expressed as free $\mathrm{Cu}$ ion concentration, EC50s varied with sampling sites in the range of $1-4.8 \mu \mathrm{g} \mathrm{L}^{-1}$. The difference in $\mathrm{EC}_{50} \mathrm{~s}$ expressed as free $\mathrm{Cu}$ ion among water samples could be because the effects of competing cations (i.e. $\left[\mathrm{H}^{+}\right],\left[\mathrm{Ca}^{2+}\right]$ and $\left[\mathrm{Mg}^{2+}\right]$ ) have not been included in the model. The presence of competing cations in natural waters and in culture medium may decrease the amount of $\mathrm{Cu}$ bound 


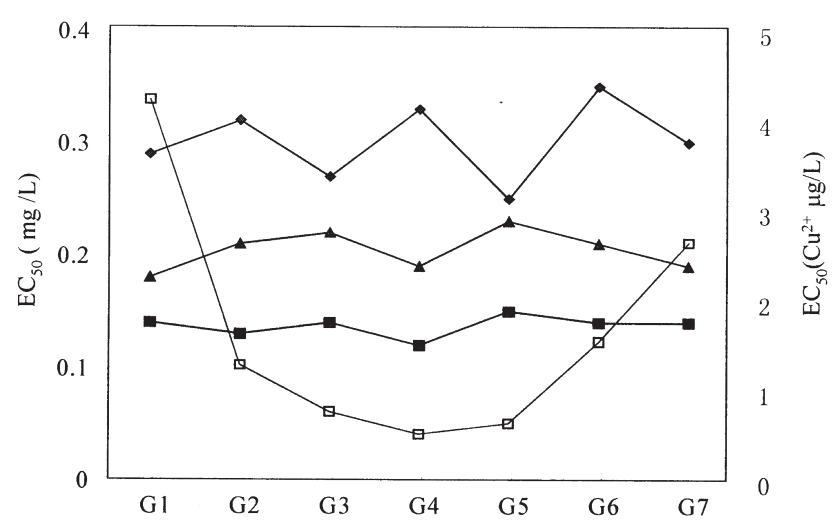

Figure 4 Measured $E_{50}$ versus complexation capacity in Guanting Reservoir waters $\left(y=0.0009 x+0.0 .2443, \mathrm{R}^{2}=\right.$ $0.8963, \mathrm{n}=7)$. Data were obtained from Table 3 and 4.

to biotic receptor sites. ${ }^{29} \mathrm{EC}_{50}$ was best expressed using bioavailable concentration of $\mathrm{Cu}\left(\left[\mathrm{Cu}^{*}\right]\right)$ as the indicator, where it ranged from 0.13 to $0.15 \mathrm{mg} \mathrm{L}^{-1}$ and were almost independent of water composition.

This suggested that median inhibition of $\mathrm{Cu}$ to $Q 67$ in Guanting Reservoir waters was $0.14 \mathrm{mg} \mathrm{L}^{-1}$ in terms of $\left[\mathrm{Cu}^{*}\right]$. It should be noted that $\left[\mathrm{Cu}^{*}\right]$ in spiked natural water was obtained in a similar way as it was obtained in reconstituted waters. Therefore, its value should be comparable to those obtained in laboratory simulations. However, while $\mathrm{EC}_{50}$ in terms of $\left[\mathrm{Cu}^{*}\right]$ in spiked reservoir waters was predicted to be $0.14 \mathrm{mg} \mathrm{L}^{-1}$, it varies from 0.16 to $0.19 \mathrm{mg} \mathrm{L}^{-1}$ in reconstituted waters from empirical Eqns of (1)-(5).

When expressed as total concentration of $\mathrm{Cu}$, the observed $\mathrm{EC}_{50} \mathrm{~s}$ could be linearly correlated to the measured $\mathrm{Cu}$ complexation capacities of waters (Figure $\left.5, R^{2}=0.8963, n=7\right)$. The results showed significant influence of DOC from Guanting Reservoir on the toxicity of $\mathrm{Cu}$. For example at site G06, complexation capacity was highest $\left(0.128 \mathrm{mg} \mathrm{L}^{-1}\right)$, the corresponded $\mathrm{EC}_{50}$ was highest $\left(0.35 \mathrm{mg} \mathrm{L}^{-1}\right)$. Generally, the influences of DOC on the toxicity of $\mathrm{Cu}$ could be excluded either by measuring the complexation capacity or a measured water-effect ratio (WER). ${ }^{30}$ The current study provides an alternative to exclude inert forms of $\mathrm{Cu}$ from the total. $\left[\mathrm{Cu}^{*}\right]$ reflected the heterogeneity of natural organic matter and the effects of water chemistry on $\mathrm{Cu}$ toxicity in Guanting reservoir natural waters. Since $\mathrm{EC}_{50}$ expressed in terms of [Cu*] is universal, the hypothesis needs to be confirmed by application the approach for other water bodies.

\section{CONCLUSIONS}

The bioavailable concentration of $\mathrm{Cu}$, or $\left[\mathrm{Cu}^{*}\right]$ has been defined here to predict growth inhibition of $\mathrm{Cu}$ on Q67. The relationship between $\mathrm{EC}_{50}$ and concentration of $\mathrm{Cu}$ on $Q 67$ could be formulated through laboratory

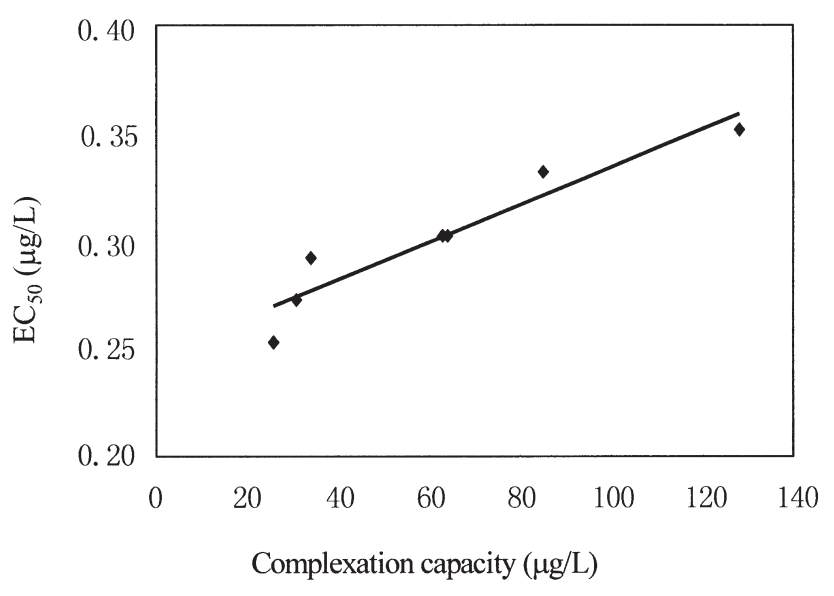

Figure $5 \mathrm{EC}_{50}$ s expressed by different $\mathrm{Cu}$ speciation to $Q 67$ in $\mathrm{Cu}$ spiked Ganting reservoir waters $E C_{50}-\left[C u_{T}\right]$, $\square E C_{50^{-}}\left[\mathrm{Cu}^{2+}\right], \Delta E C_{50^{-}}\left[\mathrm{Cu}_{\text {labile }}\right], \boldsymbol{E} \mathrm{C}_{50^{-}}\left[\mathrm{Cu} \mathrm{Cu}^{*}\right]$.

simulation experiments in the presence of $\mathrm{NaHCO}_{3}$, chloride, EDTA and FA and $\mathrm{EC}_{50}$ in terms of $\left[\mathrm{Cu}^{*}\right]$ could be obtained by excluding the inert forms of $\mathrm{Cu}$ species from the total. A procedure of applying both DAM-DPASV measurements and model calculation to obtain $\left[\mathrm{Cu}^{*}\right]$ in FA-containing reconstituted waters and spiked natural waters was proposed. It was found that the $\mathrm{EC}_{50}$ in terms of bioavailable concentration of $\mathrm{Cu}$ on $Q 67$ in reconstituted waters was in range of 0.16 to $0.19 \mathrm{mg} \mathrm{L}^{-1}$ and $0.14 \mathrm{mg} \mathrm{L}^{-1}$ in spiked natural waters. The proposed procedure provides an alternative to FIAM model. Moreover, it provides a means to measure the bioavailable concentration of $\mathrm{Cu}$ in natural water and to predict its toxicity in complex media.

\section{ACKNOWLEDGEMENTS}

This study was supported by International Copper Association (ICA-TP0602) and Natural Science Foundation of China (40071073).

\section{REFERENCES}

1 Allen, H.E., David, J. and Hansen, D.J. Water Environ. Res., 1996, 68, 42-54.

2 Allen, H.E. Sci. Total Environ. 1993, 134, $23-34$.

3 Morel, F.M.M. Principles of Aquatic Chemistry, John Wiley \& Sons, New York, 1983. pp301.

4 Campbell, P.G.C. Metal Speciation and Bioavailability in Aquatic Systems, Tessier, A. and Turner, D.R. (eds) John Wiley \& Sons, New York, 1995. pp.45-102.

5 Morel, F.M.M. and Hering, J. Principles and Applications of Aquatic Chemistr,. John Wiley \& Sons, New York, 1993.

6 Erickson, R.J., Benoit, D.A. and Mattson, V.R. Environ. Toxicol. Chem., 1996, 15, 181-193. 
7 Playle, R.C., Gensemer, R.W. and Dixon, D.G. Environ. Toxicol. Chem., 1992, 11, 381-391.

8 Di Toro, D.M., Allen, H.E. and Bergman, H.L. Environ. Toxicol. Chem., 2001, 20, 2383-2396.

9 Santore, R.C., Di Toro, D.M. and Paquin, P.R. Environ. Toxicol. Chem., 2001, 20, 2397-2402.

10 U.S. Environmental Protection Agency. 1999. Integrated approach to assessing the bioavailability and toxicity of metals in surface waters and sediments. USEPA822-E-99-001. Technical Report. Office of Water of the EPA Science Advisory board, Washington, DC, USA.

11 U.S. Environmental Protection Agency. 2000. An sab report: review of the biotic ligand model of the acute toxicity of metals.. EPA-SAB-EPE-00-006. Prepared by the Ecological Processes and Effects Committee of The Science Advisory Board Washington, DC, USA.

12 Florence, T.M. Analyst, 1986, 111, 489-505.

13 Morrison, G.M., Florence, T.M. and Stauber, J.L. Electroanalysis, 1990, 2, 9-14.

14 Florence, T.M., Morrison, G.M. and Stauber, J.L. Sci. Total Environ. 1992, 125, 1-13.

15 T.M. Florence, Analyst, 1992, 117, 551-553.

16 Wang, Z.J., Huang, S.B. and Liu, Q. Environ. Toxicol. Chem., 2002, 21(9) (in press).

17 Zhu, W.J., Wang, Z.J. and Chen, X.Y. Oceanologia et Limnologia Sinicaand (China), 1994, 25, 273-279.

18 Jin, X.C. Lakes in China-research of their environment, (Vol.2), pp.7, Ocean Publishing house, Beijing, China. 1995.
19 Stumm, W. and Morgan, J.J. Aquatic chemistry: chemical equilibria and rates in natural water, pp.873-899, John Wiley and Sons, Inc., New York, 1995,

20 Vasconcelos, M.T., Azenha, M.A. and Lage, O.M. Anal. Biochem., 1996, 241, 248-253.

21 Wang, Z.J. Acta Scientiae Circumstantiae (China), 1987, 7, 313-318.

22 Bulich, A.A. A practical and reliable method for monitoring the toxic sample, Process Biochemistry, 1982, March/April, 45-47.

23 Zhou, Y.X. and Zhang, Z.S. Methods For Aquatic Bioassays, pp.114-121, Agricultural Publishing House. Beijing, China, 1989,

24 Wang, Z.J. and Stumn, W. Neth. J. Agric. Sci., 1987, 35, 231-240

25 Carter, R.J., Hoxey, A. and Verheyen, T.V. Sci. Total Environ., 1992, 125, 25-31.

26 Sarin, C., Hall, J.M. and Cotter-howells, J. Environ. Toxicol. Chem., 2000, 19, 259-264.

27 China National Environmental Protection Agency, 2000. Environmental quality standard for surface water. GHZB-1-1999. China -NEPA, Beijing, China.

$28 \mathrm{Ma}$, M., Zhao, H.F. and Wang, Z.J. J. Hygiene Res.(China), 2001, 30, 355-357.

29 Mayer, J.S., Santore R.C. and Bobbitt, J.P. Environ. Sci. Technol., 1999, 33, 913-916.

30 U.S. Environmental Protection Agency, 1994. Water Quality Standards Handbook. U.S. Environmental Protection Agency, Office of Water, Washington, DC, USA. 
